\title{
Faktor-Faktor Yang Memengaruhi Beta Saham Berbasis Syariah Di Bursa Efek Indonesia Dengan Penerapan Data Panel Common Effect (Periode Tahun 2013-2018)
}

\author{
Sunaryo $^{1}$, Elfiswandi ${ }^{2}$, Muhammad Fikri Ramadhan ${ }^{2}$ \\ ${ }^{1}$ Universitas Islam As-syafi'iyah Jakarta, Indonesia \\ ${ }^{2}$ Universitas Putra Indonesia YPTK Padang, Indonesia \\ E_mail : sunaryo56@gmail.com
}

\begin{abstract}
Abstrak
Tujuan dari penelitian ini adalah untuk menguji efek dari Inflasi, Kurs dan Suku Bunga dan Leverage pada Risiko Sistematis. Sampel penelitian ini adalah saham-saham dalam kategori syariah dalam kelompok JII (Jakarta Islamic Index) yang terdaftar di Bursa Efek Indonesia (BEI) periode 2013-2018 dengan menggunakan metode purposive sampling. Ada 41 saham yang dipilih sebagai sampel. Metode analisis yang digunakan adalah regresi data panel dengan common effect. Menggunakan regresi data panel dengan analisis common effect, diketahui bahwa Inflasi, Kurs dan Leverage berpengaruh positif signifikan terhadap Risiko Sistematis. Namun Suku Bunga berpengaruh negatif signifikan terhadap Risiko Sistematis
\end{abstract}

Kata kunci: Inflasi, Kurs, Suku Bunga Leverage dan Risiko Sistematis

\section{Pendahuluan}

Perkembangan bidang investasi di pasar modal Indonesia cukup pesat, baik dalam bentuk saham maupun obligasi. Investor yang berinvestasi di pasar modal Indonesia tidak hanya investor domestik investor asingpun ikut berinvestasi. Berdasarkan sumber CNN Indonesia, investor asing masih mendominasi kepemilikan ekuitas di pasar modal Indonesia, dimana nilai efek yang tersimpan di Kustodian Sentral Efek Indonesia (KSEI), akhir tahun 2018 asing terpantau menguasasi Rp1.857 triliun setara 52,17 persen ekuitas. Sementara domestik menguasai Rp1.703 triliun, setara 47,83 persen.

Pasar modal di Indonesia yang dikenal dengan Bursa Efek Indonesia (BEI) terdapat 9 sektor perusahaan, yaitu (1) Pertanian, (2) Pertambangan, (3) Industri Dasar dan Kimia, (4) Aneka Industri, (5) Industri Barang Konsumsi, (6) Property, Real Estat \& Konstruksi Bangunan, (7) Infrakstruktur, Utilititas \& Transportasi, (8) Finansial, dan (9) Perdagangan Jasa \& Investasi. Sampai dengan akhir tahun 2018 perusahaan yang listing di BEI sebanyak 555 perusahaan.

Bagi investor yang memperhatikan penerapan syariat agama Islam, di BEI menyediakan pilihan produk saham yang berbasis syariah. Pengertian saham yang berbasis saham syariah berdasarkan undang-undang maupun peraturan OJK lainnya, yaitu ada dua jenis saham syariah yang diakui di pasar modal Indonesia. Pertama, saham yang dinyatakan memenuhi kriteria seleksi saham syariah berdasarkan peraturan OJK Nomor 35/POJK.04/2017 tentang Kriteria dan Penerbitan Daftar Efek Syariah, kedua adalah saham yang dicatatkan sebagai saham syariah oleh emiten atau perusahan publik syariah berdasarkan peraturan OJK no. 17/POJK.04/2015.

Pergerakan harga saham syariah dapat diamati melalui Jakarta Islamic Index (JII). JII sebagai indeks saham syariah diluncurkan pertama kali di pasar modal Indonesia pada tanggal 3 Juli 2000. Konstituen JII hanya terdiri dari 30 saham syariah paling likuid yang tercatat di BEI. [1] 
mengemukakan, BEI menentukan dan melakukan seleksi saham syariah yang menjadi konstituen JII sebagai berikut :

1. Saham dipilih harus sudah tercatat paling tidak 3 bulan terakhir, kecuali saham yang termasuk 10 kapitalisasi besar.

2. Mempunyai Rasio hutang terhadap Aktiva tidak lebih besar dari $90 \%$ dilaporan keuangan tahunan atau tengah tahun.

3. Dari yang masuk kriteria 1 dan 2, dipilih 60 saham dengan urutan rata-rata kapitalisasi pasar terbesar selama satu tahun terakhir.

4. Kemudian dipilih 30 saham dengan urutan tingkat likuiditas rata-rata nilai perdagangan regular selama tahun terakhir.

Bagi investor maupun calon investor pergerakan JII dapat digunakan sebagai referensi dalam berinvestasi di BEI dalam rangka untuk mendapatkan imbal hasil.

Investor yang berinvestasi saham di pasar modal mengharapkan untuk memperoleh return yang utama dalam bentuk capital gain. Namun investor harus menyadari bahwa disamping kemungkinan mendapatkan keuntungan, tidak menutup kemungkinan mereka juga akan mengalami kerugian. Keuntungan (return) dan kerugian (loss) tersebut sangat dipengaruhi oleh kemampuan atau keahlian investor dalam menganalisis keadaan harga saham. Informasi tentang perusahaan mana yang akan membawakan keuntungan atau kerugian bagi investor dapat ditinjau dari faktorfaktor yang mempengaruhi pergerakan harga saham JII, yaitu faktor internal dan faktor eksternal. Pergerakan JII di BEI selama kurun waktu enam tahun disajikan pada tabel 1 berikut ini.

Tabel 1. Perkembangan JII Di Bursa Efek Indonesia Tahun 2013-2018

\begin{tabular}{ccccccc}
\hline & \multicolumn{6}{c}{ Tahun } \\
\cline { 2 - 7 } & $\mathbf{2 0 1 3}$ & $\mathbf{2 0 1 4}$ & $\mathbf{2 0 1 5}$ & $\mathbf{2 0 1 6}$ & $\mathbf{2 0 1 7}$ & $\mathbf{2 0 1 8}$ \\
\hline JII & 586.89 & 691.04 & 607.78 & 701.76 & 759.07 & 685.22 \\
\hline
\end{tabular}

Sumber : BEI

Dari tabel 1 di atas terlihat, JII dari tahun 2013 sampai dengan tahun 2017 cenderung meningkat, namun pada tahun 2018 mengalami penurunan, hal ini menggambarkan terjadinya penurunan harga saham syariah. Pada saat JII mengalami peningkatan bagi investor yang telah memiliki saham-saham syariah akan memperoleh keuntungan, sebaliknya pada saat JII mengalami penurunan bagi investor yang telah memiliki saham-saham syariah akan mengalami kerugian.

Harga saham di pasar modal mengalami volatilitas sesuai dengan permintaan dan penawaran saham. [2] mengemukakan, volatilitas harga saham disebabkan oleh faktor internal dan eksternal. Faktor internal diantaranya laporan penjualan, pengumuman pendanaan, pengumuman investasi, pengumuman laporan keuangan perusahaan, peramalan laba sebelum akhir tahun fiskal dan setelah akhir tahun fiskal, Earning Per Share (EPS), Dividen Per Share (DPS), Price Earning Ratio, Net Profit Margin, Return on Assets (ROA), dan lain-lain. Sedangkan faktor eksternal seperti perubahan suku bunga tabungan dan deposito, kurs valuta asing, inflasi, serta berbagai regulasi dan deregulasi ekonomi yang dikeluarkan oleh pemerintah. [3] mengemukakan, harga saham sangat tergantung dari prospek keuntungan yang dimiliki perusahaan, dan keuntungan tersebut tergantung kondisi makro ekonomi seperti produk domestik bruto, tingkat pengangguran, inflasi, tingkat bunga, kurs. 
Faktor yang memengaruhi volatilitas harga saham seperti yang diuraikan di atas pada dasarnya merupakan risiko yang dihadapi oleh investor. Menurut [4] faktor makro dapat menimbulkan risiko saham yang disebut sebagai risiko sistematis. Risiko sistematis adalah risiko yang berkaitan dengan perubahan yang terjadi di pasar secara keseluruhan. Perubahan pasar tersebut akan memengaruhi variabelitas return suatu investasi. Menurut Beaver, Kettler, dan Scholes dalam [5] faktor fundamental internal yang berhubungan risiko sistematis, seperti dividen payout, asset growth, leverage, liquidity, asset size, earning variability dan accounting beta. Perkembangan rata-rata risiko sistematis saham-saham syariah dalam JII yang di ukur dengan beta selama kurun waktu enam tahun disajikan pada tabel 2 berikut ini.

Tabel 2. Perkembangan Rata-Rata Risiko Sistematis Saham Syariah Di Bursa Efek Indonesia Tahun 2013-2018

\begin{tabular}{ccccccc}
\hline & \multicolumn{7}{c}{ Tahun } \\
\cline { 2 - 7 } & $\mathbf{2 0 1 3}$ & $\mathbf{2 0 1 4}$ & $\mathbf{2 0 1 5}$ & $\mathbf{2 0 1 6}$ & $\mathbf{2 0 1 7}$ & $\mathbf{2 0 1 8}$ \\
\hline Beta & 1.013 & 1.017 & 1.074 & 1.239 & 1.257 & 1.287 \\
\hline Sumber : Pefindo di olah & & & &
\end{tabular}

Dari tabel 2 di atas terlihat rata-rat beta saham-saham syariah di BEI mengalami peningkatan dari tahun 2013 sampai dengan tahun 2018. Hal ini menggambarkan meningkatnya risiko sistematis.

Penelitian terdahulu yang berhubungan dengan inflasi, suku bunga dan kurs terhadap risiko sistematis seperti [6], menemukan inflasi berpengaruh negatif signifikan terhadap beta saham, sedangkan Kurs Rupiah/USD tidak berpengaruh positif signifikan terhadap beta saham, [4] menemukan inflasi dan kurs berpengaruh positif signifikan terhadap beta saham. [8] menemukan inflasi dan tingkat suku bunga tidak berpengaruh signifikan terhadap risiko sistematis. [9] menemukan tingkat suku bunga berpengaruh positif dan signifikan terhadap risiko sistematis. [10] menemukan suku bunga berpengaruh negatif signifikan terhadap risiko sistematis.

Dari uraian tersebut di atas tergambar fenomena empiris menunjukkan risiko sistematis yang meningkat, disamping itu terdapat gap penelitian terdahulu, maka penelitian ini selain mencari faktor penyebab yang signifikan memengaruhi risiko sistematis saham-saham syariah dan juga perlu dilakukan pengujian lebih lanjut untuk mengetahui konsistensi temuan penelitian terdahaulu jika diterapkan pada kondisi lingkungan yang berbeda.

\section{Metodologi Penelitian}

Data inflasi, kurs dan BI rate diperoleh dari sumber BPS dan BI. Populasi penelitian ini adalah saham-saham dalam kategori syariah dalam kelompok JII (Jakarta Islamic Index). Teknik sampling yang digunakan adalah purposive sampling dengan kriteria saham yang masuk 30 kelompok JII dari tahun 2013 - 2018, sekurang-kurangnya pernah masuk kelompok 30 saham JII empat tahun. Data diperoleh berdasarkan publikasi Bursa Efek Indonesia. Diperoleh jumlah sampel sebanyak 41 saham syariah yang disajikan pada tabel 3 berikut ini.

Tabel 3. Daftar Saham Terpilih Sebagai Sampel

\begin{tabular}{|c|c|l|}
\hline No. & Kode & \multicolumn{2}{|c|}{ Nama Perusahaan } \\
\hline 1 & AALI & Astra Agro Lestari Tbk. \\
\hline 2 & ADRO & Adaro Energy Tbk. \\
\hline 3 & AKRA & AKR Corporindo Tbk. \\
\hline
\end{tabular}




\begin{tabular}{|c|c|l|}
\hline 4 & ANTM & Aneka Tambang (Persero) Tbk. \\
\hline 5 & ASII & Astra International Tbk. \\
\hline 6 & ASRI & Alam Sutera Realty Tbk \\
\hline 7 & BKSL & Sentul City Tbk. \\
\hline 8 & BMTR & Global Mediacom Tbk. \\
\hline 9 & BRPT & Barito Pacific Tbk. \\
\hline 10 & BSDE & Bumi Serpong Damai Tbk. \\
\hline 11 & CPIN & Charoen Pokphand Indonesia Tbk \\
\hline 12 & CTRA & Ciputra Development Tbk. \\
\hline 13 & EXCL & XL Axiata Tbk. \\
\hline 14 & HRUM & Harum Energy Tbk \\
\hline 15 & ICBP & Indofood CBP Sukses Makmur Tbk. \\
\hline 16 & INCO & Vale Indonesia Tbk. \\
\hline 17 & INDF & Indofood Sukses Makmur Tbk. \\
\hline 18 & INDY & Indika Energy Tbk. \\
\hline 19 & INTP & Indocement Tunggal Prakasa Tbk. \\
\hline 20 & ITMG & Indo Tambangraya Megah Tbk. \\
\hline 21 & JSMR & Jasa Marga Tbk \\
\hline 22 & KLBF & Kalbe Farma Tbk. \\
\hline 23 & LPKR & Lippo Karawaci Tbk. \\
\hline 24 & LSIP & PP London Sumatra Indonesia Tbk. \\
\hline 25 & LPPF & Matahari Department Store Tbk. \\
\hline 26 & MAPI & Mitra Adiperkasa Tbk \\
\hline 27 & MNCN & Media Nusantara Citra Tbk. \\
\hline 28 & MPPA & Matahari Putra Prima Tbk. \\
\hline 29 & MYRX & Hanson International Tbk. \\
\hline 30 & PGAS & Perusahaan Gas (Persero) Tbk \\
\hline 31 & PTBA & Tambang Batubara Bukit Asam (Persero) Tbk. \\
\hline 32 & PTPP & PP (Persero) Tbk. \\
\hline 33 & PWON & Pakuwon Jati Tbk. \\
\hline 34 & SCMA & Surya Citra Media Tbk. \\
\hline 35 & SMGR & Semen Indonesia (Persero) Tbk. \\
\hline 36 & SMRA & Summarecon Agung Tbk. \\
\hline 37 & TLKM & Telekomunikasi Indonesia (Persero) Tbk. \\
\hline 38 & TPIA & Chandra Asri Petrochemical Tbk. \\
\hline 39 & UNTR & United Tractors Tbk. \\
\hline 40 & UNVR & Unilever Indonesia Tbk. \\
\hline 41 & WIKA & Wijaya Karya (Persero) Tbk. \\
\hline & & \\
\hline
\end{tabular}

Tabel 4. Definisi Operasional Variabel

\begin{tabular}{|l|l|l|l|}
\hline \multicolumn{1}{|c|}{ Variabel } & \multicolumn{1}{|c|}{ Konsep } & \multicolumn{1}{c|}{ Operasional Variabel } & Skala \\
\hline Inflasi & $\begin{array}{l}\text { Kenaikan harga barang-barang } \\
\text { yang bersifat umum dan terus- } \\
\text { menerus }\end{array}$ & $\begin{array}{l}\text { Data yang digunakan dalam } \\
\text { penelitian ini adalah inflasi akhir } \\
\text { tahun 2013 hingga Desember } \\
\text { 2018. Dalam satuan persen }\end{array}$ & \\
\hline Kurs & $\begin{array}{l}\text { Kurs atau Nilai Tukar adalah } \\
\text { Harga suatu Mata Uang } \\
\text { terhadap Mata Uang lainnya }\end{array}$ & $\begin{array}{l}\text { Data yang dipakai dalam } \\
\text { penelitian ini adalah kurs tengah } \\
\text { (middle rate) antara kurs jual dan } \\
\text { kurs beli mata uang rupiah } \\
\text { terhadap dollar Amerika Serikat }\end{array}$ & \\
\hline
\end{tabular}




\begin{tabular}{|c|c|c|c|}
\hline & & $\begin{array}{l}\text { yang ditetapkan oleh Bank } \\
\text { Indonesia. Data yang digunkan } \\
\text { dalam penelitian ini adalah kurs } \\
\text { akhir tahun } 2013 \text { hingga } \\
\text { Desember } 2018 \\
\text { Kurs =Ln (Rp terhadap USD) }\end{array}$ & \\
\hline Suku Bunga & $\begin{array}{l}\text { Suku bunga merupakan harga } \\
\text { yang dibayar sehubungan } \\
\text { penggunaan dana atau modal }\end{array}$ & $\begin{array}{l}\text { Tingkat BI Rate adalah tingkat } \\
\text { suku bunga yang ditetapkan oleh } \\
\text { Bank Indonesia dalam periode } \\
\text { tertentu. Data yang digunkan } \\
\text { dalam penelitian ini adalah BI } \\
\text { rate akhir tahun } 2013 \text { hingga } \\
\text { Desember 2018. Dalam satuan } \\
\text { persen }\end{array}$ & Rasio \\
\hline Leverage & $\begin{array}{l}\text { Rasio leverage adalah } \\
\text { mengukur berapa persen aset } \\
\text { perusahaan yang dibiayai oleh } \\
\text { utang. }\end{array}$ & $\begin{array}{l}\text { Debt ratio }=\frac{\text { Total utang }}{\text { Total aset }} \times 100 \% \\
\text { Dalam satuan persen }\end{array}$ & Rasio \\
\hline $\begin{array}{l}\text { Risiko } \\
\text { Sistematis }\end{array}$ & $\begin{array}{l}\text { Risiko sistematis adalah risiko } \\
\text { yang terkait dengan pasar } \\
\text { (risiko yang tidak dapat } \\
\text { didiversifikasikan }\end{array}$ & $\begin{array}{l}\text { Beta adalah pengukur risiko } \\
\text { sistematik. } \\
\beta \mathrm{i}=\frac{\sigma \mathrm{iM}}{\sigma^{2} \mathrm{M}} \\
\sigma \mathrm{iM}=\text { kovarian return antara } \\
\text { sekuritas ke-i dengan return } \\
\text { pasar } \\
\sigma^{2} \mathrm{M}=\text { varian return pasar } \\
\text { Dalam satuan indeks }\end{array}$ & Rasio \\
\hline
\end{tabular}

Metode analisis yang digunakan adalah model regresi data panel common effect dengan General Leash Square dengan formula berikut:

$$
\mathrm{Y}_{\mathrm{it}}=\beta_{0 \mathrm{i}}+\beta_{1} \mathrm{X} 1_{\mathrm{it}}+\beta_{2} \mathrm{X} 2_{\mathrm{it}}+\beta_{3} \mathrm{X} 3_{\mathrm{it}}+\beta_{4} \mathrm{X} 4_{\mathrm{it}}+\varepsilon_{\mathrm{it}}
$$

Keterangan:

$\beta_{0 \mathrm{i}}=$ Konstanta

$\mathrm{Y}=$ Risiko Sistematis; X1 = Inflasi; X2 = Kurs; X3 = BI Rate, X4 = Leverage

$\mathrm{i}=$ saham-saham, $\mathrm{t}=$ waktu, $\varepsilon=$ Error/variabel gangguan

\section{Hasil dan Pembahasan}

\section{Hasil Penelitian.}

Berdasarkan pengolahan data dengan software Eviews9 dihasilkan ringkasan hasil pengujian regresi data panel dengan metode common effect sebagai berikut:

Tabel 5. Regresi Model Risiko Sistematis

Dependent Variable: Beta

\begin{tabular}{ccccc}
\hline \hline Variable & Coefficient & Std. Error & t-Statistic & Prob. \\
\hline \hline C & -20.65597 & 5.726618 & -3.607010 & 0.0004
\end{tabular}




\begin{tabular}{lrrrr}
\multicolumn{1}{c}{ INFLASI } & 4.029812 & 1.597521 & 2.522541 & 0.0123 \\
$\quad$ KURS & 2.323782 & 0.600616 & 3.868998 & 0.0001 \\
\multicolumn{1}{c}{ BE RATE } & -8.903576 & 1.508794 & -5.901119 & 0.0000 \\
& 0.327898 & 0.044968 & 7.291854 & 0.0000 \\
\hline \hline Weighted Statistics & & \\
\hline \hline R-squared & 0.275474 & & \\
Adjusted R-squared & 0.263036 & & & \\
S.E. of regression & 0.383997 & & & \\
F-statistic & 22.14742 & & \\
Prob(F-statistic) & 0.000000 & & & \\
\hline \hline
\end{tabular}

Berdasarkan tabel 5 dapat dirumuskan bersamaan model regresi data panel sebagai berikut: Model Risiko Sistematis :

$$
Y=-20,655+4,0298 X 1+2,3237 X 2-8,9035 X 3+0,3278 X 4
$$

\section{Uji Signifikansi Simultan (Uji Statistik F)}

Dari tabel 5 untuk model Risiko Sistematis terlihat nilai $\mathrm{F}$ sebesar 22,14 dan nilai signifikansi sebesar 0,0000 yang lebih kecil dari 0,05. Maka dapat disimpulkan bahwa model regresi Risiko Sistematis memenuhi Goodness of Fit dan layak untuk digunakan sebuah model.

\section{Koefisien Determinasi $\left(\mathbf{R}^{2}\right)$}

Dari tabel 5 terlihat nilai koefisien Adjusted R-squared sebesar 0,2630 atau 26,30\% yang menunjukkan bahwa 26,30\% variasi Risiko Sistematis (Y) dapat dijelaskan dengan variasi variabel bebas X1, X2, X3 dan X4, sedangkan selebihnya yakni sebesar 73,70\% dijelaskan oleh variabel lain diluar model.

Berdasarkan pengujian terhadap koefisien regresi metode regresi data panel dengan model common effect secara parsial menggunakan uji-t dapat dibuktikan untuk model Resiko Sistematis bahwa X1 (Inflasi) berpengaruh positif signifikan terhadap Risiko Sistematis (Y) dengan nilai probabilitasnya sebesar 0,0123 lebih kecil dari $\alpha=0,05$. X2 (Kurs) berpengaruh positif signifikan terhadap Risiko Sistematis (Y) dengan nilai probabilitasnya sebesar 0,0001 lebih kecil dari $\alpha=$ 0,05. X3 (BI Rate) berpengaruh negatif signifikan terhadap Risiko Sistematis (Y) dengan nilai probabilitasnya sebesar 0,0000 lebih kecil dari $\alpha=0,05$. X4 (Leverage) berpengaruh positif signifikan terhadap Risiko Sistematis (Y) dengan nilai probabilitasnya sebesar 0,0000 lebih kecil dari $\alpha=0,05$.

\section{Pembahasan.}

Hipotesis pertama pada penelitian ini adalah inflasi berpengaruh positif terhadap risiko sistematis. Berdasarkan hasil uji statistik diperoleh bahwa inflasi berpengaruh positif dan signifikan terhadap risiko sistematis. Sehingga hipotesis pertama dapat diterima. Kondisi perekonomian memburuk yang ditandai terlalu tingginya inflasi dapat mengakibatkan turunnya pendapatan riil yang diperoleh investor dari investasi, sehingga hal ini akan merupakan sinyal negatif, dan pada akhirnya risiko sistematis meningkat. Sebaliknya, jika inflasi suatu negara mengalami penurunan, maka hal ini akan merupakan sinyal yang positif bagi investor seiring dengan turunnya risiko daya beli uang dan risiko penurunan pendapatan riil, sehingga menyebabkan risiko sistematis menurun. Hasil penelitian ini sejalan dengan penelitian yang dilakukan oleh [7], [10], yang menemukan inflasi berpengaruh positif dan signifikan terhadap risiko sistematis. 
Hipotesis kedua pada penelitian ini adalah kurs berpengaruh positif terhadap risiko sistematis. Hasil penelitian ini terbukti bahwa kurs dapat meningkatkan risiko sistematis yang sesuai dengan teori yang diungkapkan oleh [3] salah satu faktor makro ekonomi yang berpengaruh terhadap investasi di suatu negara adalah nilai tukar mata uang (exchange rate). Menguatnya kurs rupiah terhadap mata uang asing akan menurunkan biaya impor bahan baku untuk produksi, dan akan menurunkan tingkat suku bunga yang berlaku. Menurunnya biaya impor bahan baku dan menurunnya suku bunga akan menyebabkan meningkatnya laba perusahaan, hal ini menjadi sinyal yang positif bagi investor, sehingga menyebabkan volatilitas harga saham menurun dan akhirnya berdampak menurunnya risiko sistematis. Hasil penelitian ini sesuai dengan penelitian [7] yang menemukan kurs berpengaruh positif dan signifikan terhadap risiko sistematis. Hipotesis ketiga pada penelitian ini adalah suku bunga berpengaruh positif terhadap risiko sistematis. Berdasarkan hasil uji statistik diperoleh bahwa suku berpengaruh negatif dan signifikan terhadap risiko sistematis. Sehingga hipotesis ketiga tidak diterima. Secara teoritis perubahan suku bunga akan mempengaruhi harga saham secara terbalik, citeris paribus. Artinya, jika suku bunga meningkat, maka harga saham akan turun, citeris paribus, demikian pula sebaliknya. Seperti yang dikemukakan oleh [11], risiko tingkat bunga merupakan risiko yang timbul akibat perubahan tingkat bunga yang berlaku di pasar modal. Namun hasil penelitian ini menunjukan bahwa suku bunga berpengaruh signifikan negatif terhadap risiko sistematis, artinya jika suku bunga (BI rate) meningkat akan menyebabkan risiko sistematis menurun. Hal ini disebabkan karena naiknya BI rate tidak begitu signifikan, dimana BI rate tahun 2017 sebesar 6\% dan tahun 2018 meningkat menjadi 7,5\% (masih single degit) yang menyebabkan investor domestik maupun asing tidak tertarik untuk investasi di pasar uang, sehingga tidak menyebabkan harga saham bervolatilitas, dan akhirnya risiko sistematis menurun. Disamping itu bagi investor yang beragama Islam yang berinvestasi pada saham-saham yang berbasis syariah yang menerapkan syariat tidak terpengaruh oleh meningkatnya BI rate yang berbasis riba, dan juga saham-saham dalam kategori syariah termasuk dalam kategori likuiditas transaksi yang tinggi atau mudah diperjualbelikan. Hasil penelitian ini sesuai dengan penelitian terdahulu yang dilakukan oleh [10] yang menemukan suku bunga berpengaruh negatif dan signifikan terhadap risiko sistematis. Hipotesis keempat pada penelitian ini adalah leverage berpengaruh positif terhadap risiko sistematis. Berdasarkan hasil uji statistik diperoleh variabel leverage berpengaruh positif dan signifikan terhadap risiko sistematis yang diukur dengan Beta. Hasil penelitian ini terbukti bahwa leverage dapat meningkatkan risiko sistematis yang sesuai dengan teori yang diungkapkan oleh [12] yang menyatakan bahwa semakin tinggi rasio hutang terhadap total aset maka semakin besar risiko keuangan yang ditanggung perusahaan, semakin rendah risiko hutang terhadap total aset maka semakin rendah risikonya. Dengan kata lain leverage berpengaruh positif terhadap risiko. Demikian juga [5] menyatakan, leverage diprediksi mempunyai hubungan positif dengan beta. Hasil penelitian ini sesuai dengan penelitian [13] yang menemukan leverage berpengaruh positif dan signifikan terhadap risiko sistematis. Demikian juga [14] menemukan, leverage berpengaruh positif dan signifikan terhadap risiko sistematis.

Anda dapat memasukan hasil dan catatan diskusi. Hasilnya disajikan dalam format yang dapat diakses oleh pembaca (misalnya dalam grafik, tabel, diagram atau teks tertulis). Perhatikan bahwa data mentah biasanya dimasukkan dalam lampiran.

\section{Kesimpulan}

Penelitian ini bertujuan menguji pengaruh Inflasi, Kurs, Suku Bunga dan Leverage terhadap Risiko Sistematis dengan studi empiris pada saham-saham Jakarta Islamic Index di Bursa Efek Indoensia dengan menerapkan model regresi data panel common effect. Metode regresi data panel merupakan kombinasi dari data time series dengan sepuluh periode pengamatan (2013-2018) dan data cross section dengan 41 saham syariah yang terpilih sebagai sampel penelitian. Hasil penelitian ini menemukan Inflasi berpengaruh positif dan signifikan terhadap Risiko Sistematis. 
Kurs berpengaruh positif dan signifikan terhadap Risiko Sistematis. Suku Bunga berpengaruh negatif dan signifikan terhadap Risiko Sistematis. Leverage berpengaruh positif dan signifikan terhadap Risiko Sistematis.

Dalam rangka untuk pengembangan lebih lanjut dari hasil penelitian ini, maka peneliti selanjutnya dapat mempertimbangkan variabel lain yang diduga dapat memengaruhi Risiko Sistematis. Jumlah sampel untuk penelitian selanjutnya dapat menambah sampel dengan menambah periode penelitian. Model analisis dalam penelitian ini menggunakan data panel dengan metode common effect, bagi penelitian yang akan datang dapat mempertimbangkan metode fixed effect atau random effect, sebagai upaya untuk mendapatkan hasil analisis data yang lebih akurat.

\section{Daftar Isi}

[1] I. Fahmi, Manajemen Keuangan Perusahaan Dan Pasar Modal. Jakarta: Mitra Wacana Media, 2014.

[2] I. Z. Alwi, Pasar Modal Teori Dan Aplikasi. Jakarta: Yayasan Pancur Siwah, 2008.

[3] E. Tandelilin, Portofolio Dan Analisis Investasi Teori Dan Aplikasi, Pertama. Yogyakarta: Kanisius, 2010.

[4] Sunariyah, Pengantar Pengetahuan Pasar Modal, Keenam. Yogyakarta: Upp Stim Ykpn, 2013.

[5] H. Jogiyanto, Teori Portofolio Dan Analisis Investasi, Kesepuluh. Yogyakarta: Bpfe, 2017.

[6] A. Sarumaha, “Analisis Pengaruh Makro Ekonomi Dan Faktor Fundamental Perusahaan Terhadap Beta Saham Pada Industri Pertambangan Yang Terdaftar Di Bursa Efek Indonesia,” J. Ilm. Widya Ekon., Vol. 1, No. 2, Pp. 104-110, 2017.

[7] Yolla Fara Ardwita, "Analisis Pengaruh Variabel Fundamental Perusahaan Dan Makro Ekonomi Terhadap Risiko Sistematis Pasar Modal Konvensional Dan Syariah," J. Ilm. Mhs. Fak. Ekon. Dan Bisnis. Univ. Brawijaya, Vol. 6, No. 2, 2016.

[8] F. D. Dan Y. I, “Analisis Pengaruh Inflasi, Tingkat Suku Bunga, Dividend Payout Ratio, Dan Current Ratio Terhadap Risiko Sistematis (Studi Pada Perusahaan Bumn Yang Terdaftar Di Bursa Efek Indonesia Periode 2011-2013)," J. E-Proceeding Manag., Vol. Vol.2, No. No.2, Pp. 1376-1382, 2015.

[9] P. Vanesha, "Inflasi, Nilai Tukar, Suku Bunga Terhadap Risiko Sistematis Pada Perusahaan Sub-Sektor Food And Beverage Di Bei,” Vol. 1, No. 3, Pp. 189-196, 2013.

[10] Fitriawati, "Pengaruh Uang Yang Beredar (M2), Kurs, Inflasi, Dan Tingkat Buku Bunga Sbi Terhadap Beta Saham Syariah (Jii) Dan Indeks Harga Saham Gabungan (Ihsg)," Repository.Uinjkt.Ac.Id, 2009.

[11] A. Halim, "Analisis Investasi," Jakarta: Salemba Empat, 2005.

[12] J. M. Horne, James C. Van Dan Wachowicz, "Prinsip-Prinsip Manajemen Keuangan. Edisi 13.," Jakarta: Salemba Empat., 2012.

[13] E. Tandelilin, "Determinants Of Systematic Risk: The Experience Of Some Indonesian Common Stock," J. I-Lib Ugm, 1997.

[14] N. Rochmah, Latifatul; Hidayati, "Analisis Pengaruh Financial Leverage Terhadap Risiko Sistematis Yang Di Moderatori Size Perusahaan Pada Industri Semen Yang Terdaftar Di Bei Periode 2013-2016," J. Ilm. Ris. Akunt., Vol. 7, No. 4, Pp. 43-55, 2018. 